\title{
PARTIAL SUMMARY JUDGMENTS UNDER RULE 56(a)
}

Even where a defendant admits facts in his answer which show that he is liable for a measurable part of the plaintiff's claim, federal courts have rarely entered judgment for that amount until the full trial has been completed. In spite of rule 56(a) of the Federal Rules of Civil Procedure which provides that "a party seeking to recover upon a claim ... may ... move for a summary judgment in his favor upon all or any part thereof," 1 plaintiffs have been denied the use of money admittedly due them. The possibility of forcing a settlement for less than the court would eventually award, and the desire to retain use of the money during the several years that the case may be in the courts, prompt defendants to refuse payment. ${ }^{2}$ Thus money due on sales contracts, ${ }^{3}$ insurance claims, ${ }^{4}$ loans, ${ }^{5}$ or salaries, ${ }^{6}$ for example, can be withheld from deserving plaintiffs for long periods of time.

In Bamberger Broadcasting Serv., Inc. v. William Irving Hamilton, Inc., ${ }^{7}$ rule 56(a) was properly applied. The plaintiff sought payment for three months of radio advertising and defendant conceded that one

1 FED. R. Crv. P. 56(a) (emphasis added). "Partial summary judgment," as used in this comment, refers to the granting of judgment on a portion of a single claim. It is not used to refer to the granting of judgment on a single claim where more than one claim is presented in a case.

2 Rule 56(b) provides that defendants may move for summary judgment as to "all or any part" of a claim. This comment focuses on partial summary judgments for plaintiffs since the only time a defendant really needs a partial judgment, as opposed to a pre-trial order, is when his credit is impaired because of a large pending suit. If he can get judgment in his favor on part of the suit, his credit as well as state of mind may improve. The analysis of doctrinal arguments herein applies equally to rules 56(a) and (b).

3 Liberty Die \& Button Mould Corp. v. Consolidated Button \& Buckle Corp., 160 N.Y.S.2d 728 (Sup. Ct. 1957). Plaintiff shipped $\$ 137.50$ worth of merchandise to defendant, who returned a portion and asked for a $\$ 35.00$ credit. Plaintiff issued only a $\$ 30.00$ credit. The court held that plaintiff was entitled to partial summary judgment for $\$ 100$ since that amount was not in controversy. N.Y.R. CIv. PRAc. 114 specifically authorizes such partial judgments; see note 43 infra.

4 Commonwealth Ins. Co. v. O. Henry Tent \& Awning Co., 266 F.2d 200 (7th Cir. 1959).

5 Meadow Brook Nat'l Bank v. De Giacomo, 23 Misc. 2d 270, 206 N.Y.S.2d 224 (Sup. Ct. 1960). Partial summary judgment was entered for the face amount of the notes and the question of interest rates was held over for trial.

6 Sloane v. Land, 16 F.R.D. 242 (S.D.N.Y. 1954). The employee sued the employer for $\$ 2,600$, and $\$ 2,100$ liability was admitted. The court refused to enter partial summary judgment.

733 F. Supp. 273 (S.D.N.Y. 1940). 
month's charges were due. Partial summary judgment was entered, and the plaintiff was free to have execution for the single month's charges. Likewise, the plaintiff in McDonald $v$. Batopilas Mining Co., ${ }^{8}$ an attorney who had represented the defendant before the Mexican Claims Commission, sought twenty per cent of the money awarded by that body. The defendant answered that there was a ten per cent statutory limit on attorney's fees. The court entered partial summary judgment for ten per cent of the award-the amount for which liability was admitted -and ordered trial as to the remainder. While there was no mention of the federal rule under which the judgment was entered, it properly fits within $56(a) .^{9}$

But since 1948, the date of McDonald, there has been no federal decision of record granting partial summary judgment. ${ }^{10}$ To the contrary, there have been numerous holdings, citing neither McDonald nor Bamberger, that the federal rules do not permit partial judgments. ${ }^{11}$

One group of cases reads rule 56(a) in terms of rule 56(d) or 54(b). For example, when the O. Henry Co. alleged fire damages of $\$ 32,000$, its insurance company offered only $\$ 14,000$ on the grounds that $\mathrm{O}$. Henry had failed to meet the reporting requirements of the policy. Partial summary judgment was entered in favor of $O$. Henry for $\$ 14,000$ and the insurance company immediately appealed. The Seventh Circuit reversed in Commonwealth Ins. Co. v. O. Henry Tent \& Awning Co., ${ }^{12}$ relying on its previous decision in Biggins $v$. Oltmer Iron Works. ${ }^{13}$ In

88 F.R.D. 226 (E.D.N.Y. 1948).

9 It is not clear whether payment was immediately made in Bamberger and McDonald. It is possible that execution was not sought for fear it would adversely affect any settlement that was in the offing. Considerations of this type are always factors in deciding whether to seek and execute a partial summary judgment.

10 A district court in Pennsylvania entered a partial summary judgment in 1948. Though the case is unreported, it is mentioned in Coffman v. Federal Labs., Inc., 171 F.2d 94, 96 (3d Cir. 1948). There is also an earlier decision in the Southern District of New York that purportedly granted partial summary judgment. The case, however, is unclear and may involve five separate claims such that the judgment entered would have been on a whole claim. Tractor \& Equip. Corp. v. Chain Belt Co., 50 F. Supp. 1001 (S.D.N.Y. 1942).

11 Rabekoff v. Lazere \& Co., 323 F.2d 865 (2d Cir. 1963); Commonwealth Ins. Co. v. o. Henry Tent \& Awning Co., 266 F.2d 200 (7th Cir. 1959); New Hampshire Fire Ins. Co. v. Perkins, 30 F.R.D. 382 (D. Del. 1962); Sloane v. Land, 16 F.R.D. 242 (S.D.N.Y. 1954).

12266 F.2d 200 (7th Cir. 1959).

13154 F.2d 214 (7th Cir. 1946). The court also cited Coffman v. Federal Labs., Inc., 171 F.2d 94 (3d Cir. 1948) (issue whether partial summary judgment which had been entered and satisfied had res judicata effect on any of the remaining issues between the parties; court held it did not, and by way of dicta expressed the view that partial summary judgments are not permitted). Coffman in turn relied on Biggins. The court in $O$. Henry also cited Leonard v. Socony-Vacuum Oil Co., 130 F.2d 535 (7th Cir. 1942) (held merely that a partial summary judgment entered under 56(d) was a pre- 
Biggins, the plaintiff salesman had sought money due him as sales representative for the defendant. The claim consisted of five items of back salary and plaintiff moved for summary judgment on two. Supporting affidavits were submitted, and after the defendant's failure to answer, the court entered partial summary judgment. On appeal the Biggins court concluded that rule 56 "does not contemplate a summary judgment for a portion of a single claim in a suit." 14 It produced a curious argument: since rule 56(d) provides for a pre-trial order, rule 56(a) must provide for no more. ${ }^{15}$

Authority for this proposition was conspicuously wanting, ${ }^{16}$ and it cannot stand analysis. Rule 56(d) reads:

If on motion under this rule judgment is not rendered upon the whole case or for all the relief asked and a trial is necessary, the court ... shall if practicable ascertain what material facts exist without substantial controversy. ... It shall thereupon make an order specifying the facts that [are not in controversy] . . . .

Rule 56(a) speaks of a "judgment," and rule 56(d) of an "order." It seems likely that the draftsmen intended some difference. Indeed, according to the Advisory Committee Notes, ${ }^{17}$ the purpose of 56 (d) is to provide for a pre-trial order whenever the court must deny a motion for summary judgment. Since the court must consider affidavits and exhibits in passing upon the motion for summary judgment, ${ }^{18}$ rule $56(\mathrm{~d})$ allows it to reap some benefit from the time expended by narrowing the issues and shortening the eventual trial. Rule $56(\mathrm{~d})$, then, is concerned with limiting the issues for that portion of the case that remains after the motion for summary judgment under 56 (a) has been ruled upon. The

trial order and hence not appealable); Porter v. American Tobacco Co., 7 F.R.D. 106 (S.D.N.Y. 1946) (relying on Biggins; held that partial summary judgments could not be entered and confined its discussion to rules 56(d) and 54(b)); Audi Vision, Inc. v. RCA Mfg. Co., 136 F.2d 621 (2d Cir. 1943) (held that where there is a claim and a counterclaim which depend on the same underlying facts, the dismissal of either one alone is not a final decision).

14154 F.2d at 216.

15 Ibid.

16 Biggins cited no cases in support of its position. On this point, $O$ Henry cited Pasquel v. Owen, 97 F. Supp. 157 (W.D. Mo. 1951) (partial summary judgment as to liability could not be granted on the basis of evidence taken at a previous trial, since the appellate court had ordered a complete new trial); Harms, Inc. v. Tops Music Enterprises, Inc., 160 F. Supp. 77 (S.D. Cal. 1958) (partial summary judgment denied under rule $54(\mathrm{~b})$ for amount of settlement offer with no discussion as to the applicability of 56(a)); Wilbur v. Ford, 89 F. Supp. 407 (D. Mass. 1950) (partial judgment not allowed under rule 56 (d) for the amount of a surety bond, relying on Biggins, Coffman, and Audi Vision, Inc. v. RCA Mfg. Co., 136 F.2d 621 (2d Cir. 1943)).

17 Notes of the Advisory CoMmittee on Rules, 28 U.S.C. at 3317 (1946).

18 FED. R. CIv. P. 56(e). 
Biggins-O. Henry position in effect rewrites rule 56; it improperly replaces the right to execution and payment provided by $56(\mathrm{a})$ with the merely provisional remedies of $56(\mathrm{~d}) .^{19}$

A second argument implicit in Biggins and $O$. Henry is that, prior to completion of a case, rule $54(\mathrm{~b})$ is the sole determinant of when judgment may be entered. The rule states:

When more than one claim for relief is presented in an action ... the court may direct the entry of a final judgment as to one or more but fewer than all of the claims or parties only upon an express determination that there is no just reason for delay. . . .

Since this rule provides for judgment on "one or more" claims the Seventh Circuit drew the negative inference that judgment is not permitted on a portion of a claim. It drew the further inference that the language authorizing partial summary judgments in 56(a) was to be ignored because it had not been repeated in 54(b). Nothing in the federal rules supported this proposition, and there was no precedent for it.

A state court ${ }^{20}$ has suggested that first, if final judgment for partial relief may be granted freely under 56(a), there is no need for 54(b), and second, it would be unreasonable freely to permit partial summary judgments under 56(a) while they are limited to special conditions under 54(b). The first argument completely ignores that 54(b) applies to all multiple claim situations while rule 56 deals only with summary judgments. The second argument fails because it overlooks the basic similarity of purpose between the two rules. Under 54(b) the court may enter a final judgment by stating that there is no just reason for delay. If the judge does not want to enter a final judgment he may enter an "order... [which] is subject to revision at any time before the entry of judgment adjudicating all the claims. ..." This is precisely the alternative that a court has under rule 56. If the judge wishes to enter a final judgment, he can do so under 56(a); if he does not, he can enter an order under 56 (d) that is likewise subject to revision before completion of the trial.21 The only distinction between the two rules on this

19 The 56(d) order differs significantly from a partial summary judgment, since it is not final, not subject to execution, and may be revised at any time prior to the close of the trial.

20 Fontainebleau Hotel Corp. v. Young, 162 So. 2d 303 (Fla. Dist. Ct. App. 1964).

21 Where summary judgment is granted on a single claim, in a multiple claim situation, certification under 54 (b) has been required to make the judgment appealable. Hence there is the asymetrical situation that a certificate is required for summary judgment on a whole claim while there is no similar requirement for judgment on a partial claim. It would be more reasonable to exclude summary judgments entirely from the provisions of 54(b) since a judge's decision to enter a judgment under 56(a) rather than an order under $56(d)$ is tantamount to saying that there is no just reason for delay. 
point, then, is the requirement in rule $54(\mathrm{~b})$ of a formal certificate, the main function of which is to provide certainty as to whether a final judgment has been entered.22 This distinction certainly does not justify saying 56(a) must be read in light of 54(b).

In its recent decision in Rabekoff v. Lazere \& Co., ${ }^{23}$ the Second Circuit criticized the Seventh Circuit's whole approach and opened a different line of attack against partial summary judgments. The court said that a partial summary judgment is not a "final decision from which an appeal may be taken. . . ."24 Essentially, it argued that regardless of the provisions of the federal rules, the requirements of section 1291 must be independently satisfied. ${ }^{25}$ Thus, if partial summary judgments are not final decisions, they are not appealable and are really only interlocutory orders.

The weakness in the Rabekoff argument is the presumption that "final decision" has a readily ascertainable meaning, and that it imposes a rigid standard upon the courts. The "final judgment" rule, as it is popularly known, was stated by Mr. Justice Brandeis in Collins $v$. Miller:26 "the rule requires that the judgment to be appealable should be final not only as to all the parties, but as to the whole subject-matter and as to all the causes of action involved." 27 This traditional view treats each case as a single judicial unit, and no appeal is permitted without full and complete disposition of the case.

But while the "final judgment rule" has been on the books since $1789,{ }^{28}$ the courts have not always felt bound by its traditional meaning. As early as 1848 the Supreme Court allowed an appeal in Forgay v. Conrad, ${ }^{29}$ where execution had been ordered on a partial judgment, because it would have been unjust to subject the defendant to seizure of his property without the right to be heard on appeal. The Forgay

22 See Dickinson v. Petroleum Conversion Corp., 338 U.S. 507, 512 (1950).

23323 F.2d 865 (2d Cir. 1963).

$24 I d$. at 867 . Rule 56(a) was not directly involved in this case. Partial summary judgment was entered, and the trial judge certified under 54(b) because he thought that multiple claims were involved. The Second Circuit held that there was only a single claim involved and that the Judicial Code, 28 U.S.C. $\$ 1291$ (1958), forbade partial judgments on a single claim. But the statement that the trial courts in Biggins and O. Henry had exceeded their jurisdiction makes it clear that the Second Circuit would have reached the same result if the judgment had been entered under 56(a).

25 In case of an open conflict between the federal rules and the Judicial Code on the question of appellate court jurisdiction, the latter prevails. Sears, Roebuck \&: Co. v. Mackey, 351 U.S. 427 (1956).

26252 U.S. 364 (1920).

27 Id. at 370 .

28 I Stat. 84 (1789).

2947 U.S. (6 How.) 200 (1848). 
principle has shown great vitality and has been continually reaffirmed by the Supreme Court ${ }^{30}$ and the lower courts. ${ }^{31}$ Mr. Justice Frankfurter explained:

In short, the rationale of these cases is that a judgment directing immediate delivery of physical property is reviewable and is to be deemed dissociated from a provision for an accounting even though that is decreed in the same order. In effect such a controversy is a multiple litigation. . . . ${ }^{32}$

In other words, where the court divides the payment of damages into two parts it creates two separate judicial units for purposes of the final decision rule. In Sears, Roebuck of Co. v. Mackey, ${ }^{33}$ the Court saw "a need for relaxing the restriction upon what should be treated as a judicial unit for purposes of appellate jurisdiction." 34 More recently the Court noted that the final judgment rule must be given a "practical rather than a technical construction." 35 Section 1291 does nothing more than impose a requirement, on the courts to define "final decision." There is nothing about rule 56(a) which is inconsistent.

However, the doctrinal arguments may merely mask a judicial ap-

30 Local 438, Construction Union v. Curry, 371 U.S. 542, 549 (1963); Brown Shoe Co. v. United States, 370 U.S. 294, 308 (1962); Sears, Roebuck \& Co. v. Mackey, 351 U.S. 427, 432 (1956); Radio Station WOW, Inc. v. Johnson, 326 U.S. 120, 125 (1945); Gulf Refining Co. v. United States, 269 U.S. 125, 136 (1925); Hill v. Chicago \& Evanston R.R., 140 U.S. 52, 54 (1891); Farmers Loan \& Trust Co., Petitioner, 129 U.S. 206, 213 (1889); Winthrop Iron Co. v. Meeker, 109 U.S. 180, 183 (1883); Thomson v. Dean, 74 U.S. (7 Wall.) 342 (1868); Bronson v. Radiroad Co., 67 U.S. (2 Black) 524, 531 (1862).

31 Gillespie v. United States Steel Corp., 321 F.2d 518, 522 (6th Cir. 1963); Kasishke v. Baker, 144 F.2d 384, 385 (10th Cir. 1944); Victor Talking Machine Co. v. George, 69 F.2d 871, 877 (3d Cir. 1934), rev'd on other grounds, 293 U.S. 378 (1935); In re Michigan Central R.R., 124 Fed. 727, 731 (6th Cir. 1903); City of Eau Claire v. Payson, 107 Fed. 552, 557 (7th Cir. 1901); Bergh v. Ceballos, 61 Fed. 113, 115 (2d Cir. 1894).

32 Radio Station WOW, Inc. v. Johnson, 326 U.S. 120, 126 (1945).

33351 U.S. 427 (1956). Mr. Justice Jackson, speaking for the Court, has said that the purpose of $\$ 1292$ of the Judicial Code is to "allow appeals from orders other than final judgments when they have a final and irreparable effect on the rights of the parties." Cohen v. Beneficial Industrial Loan Corp., 337 U.S. 541, 545 (1949). In effect, the Court said that Congress never intended the "final judgment" rule to be binding in situations where it will work an injustice. See Local 438, Construction Union v. Curry, 371 U.S. 542 (1963); McDonnell v. Birrell, 321 F.2d 946 (2d Cir. 1963).

34351 U.S. at 432. Professor Moore has taken the position that the court is free to define "final decision" in any way that pleases it. MOORE, Judictal CODE 517 (1949). However, Professor Moore does not believe that partial summary judgments under rule 56(a) are appealable. He believes that only a pre-trial order in the nature of rule 56(d) is contemplated by rule 56(a). 6 MOORE, FEDERAL Practice $\S 56.20$ [4], at 2311 (2d ed. 1953). The difficulty with this position is discussed in note 16 supra and accompanying text.

35 Gillespie v. United States Steel Corp., 379 U.S. 148, 152 (1964), citing Cohen v. Beneficial Industrial Loan Corp., 387 U.S. 541, 546 (1949). 
prehensiveness that granting partial summary judgments would result in a flood of additional appeals. For example, partial summary judgments have been termed "obnoxious to the orderly administration of justice,"36 and numerous courts have announced a policy against "piecemeal appeals." 37 However, under current law Congress permits appeals from interlocutory orders in suits involving injunctions, ${ }^{38}$ admiralty cases, ${ }^{39}$ receiverships, ${ }^{40}$ patent infringements, ${ }^{41}$ and any case where the judge feels there is a controlling issue of law, the determination of which will speed the outcome of the litigation. ${ }^{42}$ Further, federal rule 54(b) allows appeals where judgment has been entered on one but less than all claims and the judge sees no just reason for delay. Likewise, the Forgay line of cases has permitted many additional appeals. Experience under these exceptions and in the states that permit partial judgments ${ }^{43}$ makes it seem unlikely that partial summary judgments would cause a significant increase in appeals.

Practical considerations facing the respective parties reinforce this view. Plaintiffs would only seek partial summary judgments when, first, the amount admitted is a substantial portion of the total claim. Thus, if the claim is for $\$ 10,000$ and it is clear that partial judgment can be obtained for $\$ 9,000$, the plaintiff may seek partial judgment; if he is certain to get only $\$ 100$, however, the partial judgment would not compensate for delaying the trial. Second, he would only seek partial judgment when the full trial promises to take considerable time; the

36 Commonwealth Ins. Co. v. O. Henry Tent \& Awning Co., 266 F.2d 200, 201 (7th Cir. 1959).

37 Rexford v. Brunswick-Balke-Collender Co., 228 U.S. 339 (1913); United States v. Girault, 52 U.S. (11 How.) 21 (1850); Commonwealth Ins. Co. v. O. Henry Tent \& Awning Co., 273 F.2d 163, 165 (7th Cir. 1959); In the Matter of Heddendorf, 263 F.2d 887, 889 (1st Cir. 1959).

3828 U.S.C. § 1292 (1958).

39 Ibid.

40 Ibid.

41 Ibid.

42 Ibid.

43 New York has permitted partial summary judgments for a number of years. See, e.g., Sheehan v. Andrew Cone Gen. Advertising Agency, 176 Misc. 882, 29 N.Y.S.2d 317 (Sup. Ct. 1941). Michigan and Illinois, prior to their recent adoption of the federal rules, both provided for partial summary judgments. Mich. Ct. R. 30(5) (1945); 2 ILL. LAws 1941 at 464 . Illinois will permit partial summary judgments under its new rule which is identical to 56(a). IlL. REv. STAT. ch. 110 \& 56 (1963); Ill. SUP. CT. R. 16. Michigan has had no cases under its new rules so it is difficult to predict its future course. Several states have adopted the federal rules, e.g., FLA. R. Crv. P. 1.36; MrNn. R. Crv. P. 56; Wyo. R. Civ. P. 56, and federal court decisions may be persuasive in the state interpretations. The Biggins-O. Henry view has already made itself felt in Florida. Fontainebleau Hotel Corp. v. Young, 162 So. 2d 303 (Fla. Dist. Ct. App. 1964). 
longer the prospective trial, the more desirable the partial judgment. Finally, the plaintiff would consider how badly he needed the money.

From the standpoint of the court, there would properly be reluctance to enter partial judgments except in clear-cut cases. Where the judge has doubt whether material issues are in controversy, he can enter a pre-trial order under $56(\mathrm{~d})$ and reserve the right to revise the order during the trial.

If treated this way, even where partial summary judgment has been entered it is unlikely that many would be appealed. The defendant who has admitted liability, as in $O$. Henry, would have no issues on which to base an appeal. Where the defendant has not formally admitted liability, but his answers and affidavits nonetheless make liability clear, there would likewise be little incentive for him to throw money away appealing. He might appeal solely for purposes of delay, but the cost of the appeal would in most cases certainly outweigh the value to him of a short-term delay in paying the partial amount. ${ }^{44}$

Of course even if rule 56(a) is construed to permit partial summary judgments, there may be cases where the plaintiff's counsel will believe it unwise to invoke it. $\mathrm{He}$ may believe that routine negotiations, rather than financial pressure, will lead to a higher settlement. Thus he may prefer not to have a hostile act like execution of the partial judgment interfere with the rapport between the defense counsel and himself. This attitude would be reinforced if his client had money to tide himself over until completion of the suit. But cases like $O$. Henry show that there are cases in which plaintiffs do want partial summary judgment. How many more would have been sought but for the prevailing rule cannot be estimated, but where partial summary judgment is desired there is no valid reason for the courts to refuse to grant it. Its use should accelerate the course of justice without overly taxing the judicial machinery.

44 One objection that might be raised is that the defendant's answers will simply become more evasive in order to avoid admission, thus dissipating the anticipated benefit from partial summary judgments. This is unlikely for two reasons. First, in hearing a motion for summary judgment the court also considers depositions, answers to interrogatories and affidavits in accord with rule 56(c). It would require more than simply rewording the answer to create an issue of material fact. Second, the courts could control the problem of evasive pleadings through stricter use of rule 11, which requires attorneys to certify that pleadings are not interposed for delay and authorizes the court to take "appropriate disciplinary action." 